\title{
HYBRID MAIZE AND CHILLI INTERCROPPING IN THE HILLY AREAS OF BANDARBAN
}

\author{
M. Ahmed ${ }^{1}$, S. Ishtiaque ${ }^{1 \star}$, M. M. R. Sarker ${ }^{1}$, A S M M R Khan ${ }^{1}$, A. K. Choudhury ${ }^{1}$, \\ M. K. Hasan ${ }^{1}$ F. Hossain ${ }^{1}$, S. K. Paul ${ }^{2}$ and M. U. Islam ${ }^{3}$ \\ ${ }^{1}$ On-farm Research Division, Bangladesh Agricultural Research Institute (BARI), Gazipur-1701 \\ ${ }^{2}$ Agronomy Division, Bangladesh Agricultural Research Institute (BARI), Gazipur-1701 \\ ${ }^{3}$ Oil Seed Research Center, Bangladesh Agricultural Research Institute (BARI), Gazipur-1701 \\ *Corresponding author: sheikh11ishtiaque@gmail.com
}

Keywords: intercropping, hill farming, multiple cropping, yield

\begin{abstract}
The experiment was conducted at farmers' field of On-Farm Research Division (OFRD), Bandarban during Rabi season of 2014-15 to find out suitable combination of hybrid maize and chilli intercropping system to increase system productivity and economic return. The experimental design was Randomized Complete Block (RCB) design with six dispersed replications. The maize var. BARI Hybrid Maize-9 and chilli (local) were used in the experiment. Two intercropping combinations viz., Maize single row $(100 \mathrm{~cm} \times 25 \mathrm{~cm})+2$ rows chilli $(50 \mathrm{~cm} \times 40 \mathrm{~cm})$ and Maize single row $(150 \mathrm{~cm} \times 25 \mathrm{~cm})+3$ rows Chilli $(50 \mathrm{~cm} \times 40 \mathrm{~cm})$ were evaluated against their sole crops. The highest gross return (Tk. $435040 \mathrm{ha}^{-1}$ ), net return (Tk. $366290 \mathrm{ha}^{-1}$ ) and benefit cost ratio (6.33) were recorded in maize single row $(150 \mathrm{~cm} \times 25 \mathrm{~cm})+3$ rows Chilli $(50 \mathrm{~cm} \times 40 \mathrm{~cm})$ combination. Cob yield of hybrid maize and green fruit yield of Chilli were the highest in the respective sole crops. The results revealed that maize single row $(150 \mathrm{~cm} \times 25 \mathrm{~cm})+3$ rows Chilli $(50 \mathrm{~cm} \times 40 \mathrm{~cm})$ combination might be suitable and economically profitable for the hilly areas.
\end{abstract}

\section{Introduction}

Intercropping is a traditional practice in Bangladesh. Maize (Zea mays), the third most important cereal crop of the world, is an important dual purpose crop used in human diet and animal feed. Maize has the potential to supply large amounts of energy-rich forage for animal diets, and its fodder can safely be fed at all stages of growth. The cultivation of two or more crop species simultaneously in the same field during a growing season is known as intercropping (Ofori and Stern, 1987). It has many advantages over sole cropping which provides an efficient utilization of environmental resources, reduces risk to the cost of production, provides greater financial stability for farmers, decreases pest damages, suppresses weeds growth more than monocultures, improves soil fertility through nitrogen increasing to the system and improves forage yield and quality (Francis et al., 1976). Intercropping is a crop management system involving the growing of two or more dissimilar crops in distinct row combinations simultaneously on the same land area. Intercropping involves crop intensification in respect to both time and space dimensions (Ahlawat and Sharma, 2002). Chilli is one of the major spices crop in Bangladesh cultivated in 2, 40,000 acres of land (both winter and summer) with a production of 1, 26, 000 metric ton (BBS, 2012). The review of research work done so far indicated that growth of chilli as intercrops is more beneficial than growing chilli in many situations (Aravazhi et al., 1997; Natara Jan, 1992; Sadashiv, 2004). Intercropping increases total productivity through efficient growth resources. Inter-specific competition may be minimized through judicious choice of crops (Santalla et. al., 2001). Several short duration and short stature crop like chilli may be grown 
Ahmed et al.

in association with hybrid maize. Incident light may be increased on below storey crop by changing planting geometry of hybrid maize. This experiment was conducted to find out suitable planting systems of hybrid maize and chilli intercropping system for higher productivity and economic return.

\section{Materials and Methods}

The experiment was conducted at hilly areas of Bandarban during Rabi season of 2014-15. The hybrid maize (var. BARI hybrid maize 9) and chilli local were used in this intercropping experiment. The treatment combinations were $T_{1}=$ Sole maize $(60 \mathrm{~cm} \times 20 \mathrm{~cm}), T_{2}=$ Sole chilli $(50 \mathrm{~cm} \times 40 \mathrm{~cm}), \mathrm{T}_{3}=$ Single row maize $(150 \mathrm{~cm} \times 25 \mathrm{~cm})+3$ rows chilli $(50 \mathrm{~cm} \times 40$ $\mathrm{cm})$ and $\mathrm{T}_{4}=$ Single row maize $(100 \mathrm{~cm} \times 25 \mathrm{~cm})+2$ rows chilli $(50 \mathrm{~cm} \times 40 \mathrm{~cm})$. The experiment was laid out in a randomized complete block design with three replications. The unit plot size was $4 \mathrm{~m} \times 3 \mathrm{~m}$. Seeds of maize and chilli were sown on November 25-30, 2014. Sole hybrid maize was fertilized with 250-55-l10-40-4-2 $\mathrm{kg} \mathrm{ha}^{-1} \mathrm{~N} P \mathrm{~K} \mathrm{~S} Z \mathrm{n} \mathrm{B}$, while sole chilli was grown with 120-80 -120-20-4 $\mathrm{kg} \mathrm{ha}^{-1} \mathrm{~N}$ P K S Zn and intercrop was grown with 370-55-110-40-4-2 kg, N-P-K-S-Zn-B ha ${ }^{-1}$, respectively. For sole maize the full amount of $P$ $\mathrm{K} \mathrm{S} \mathrm{Zn} \mathrm{B} \mathrm{and} \mathrm{1/2} \mathrm{N} \mathrm{were} \mathrm{applied} \mathrm{as} \mathrm{basal} \mathrm{in} \mathrm{the} \mathrm{form} \mathrm{of} \mathrm{triple} \mathrm{super} \mathrm{phosphate,} \mathrm{muriate} \mathrm{of}$ potash, gypsum, zinc sulphate, boric acid and urea, respectively. The remaining $\mathrm{N}$ was top dressed at 30 days after sowing (DAS). Chilli, $1 / 2 \mathrm{~N}$ and all other fertilizers were applied as basal. The rest amount of $\mathrm{N}$ was top dressed in three splits at 25, 50 and 70 DAT. On the other hand in case of intercrop I/3 N and all other fertilizers were applied as basal. The rest amount of $\mathrm{N}$ was top dressed in three splits at 25, 50 and 70 DAT. Irrigation was given after sowing / planting for proper establishment of crops. Subsequently three irrigations were applied at 30, 60 and 90 DAT. Two hand weedings were done at 20 and 40 DAT to keep the crops reasonably weed free. Green cob of maize was harvested at 135 and 142 DAS (5 and 12 April, 2015) and chilli was harvested at 112, 130 and I52 DAT. Maize equivalent yield was calculated by converting the yield of intercrops to the yield of Maize on the basis of prevailing market prices of individual crops. Economic analysis on the basis of net monetary return was performed to evaluate the intercropping system. Maize Equivalent Yield was calculated as:

Maize Equivalent Yield $(\mathrm{MEY})=\frac{\text { Yield of Intercrop }(\mathrm{Kg} / \mathrm{ha}) \times \times \text { Priceff intercrop }(\mathrm{Tk} . / \mathrm{ha})}{\text { Price of maize }(\mathrm{Tk} . / \mathrm{Kg})}$

The gross return, cost of cultivation, gross margin, and net return was computed from different treatments on the basis of prevailing market price of maize grain, groundnut pod and both the crop-straw and biomass. Benefit cost ratio (BCR) of different treatments was computed as follows:

$\mathrm{BCR}=\frac{\text { Gross retrun (Tk./ha) }}{\text { Total cost of production (Tk./ha) }}$

Data of both the crops were analyzed statistically and the means were adjudged by using LSD test.

\section{Results and Discussion}

Effect on maize: Plant population, cob weight with husk, yield of green cob with husk, green fodder yield and grain yields per hectare of hybrid maize were influenced significantly due to intercropping with chilli under different planting systems (Table 1). Weight of single cob was more in sole maize $(387 \mathrm{~g})$. Among intercrop treatments, maximum single cob weight was recorded in $\mathrm{T}_{4}(312 \mathrm{~g})$. The highest cob yield was found in sole maize (17.58 $\left.\mathrm{t} \mathrm{ha}^{-1}\right)$. Among 
Hybrid Maize and Chilli Intercropping in the Hilly Areas of Bandarban

intercrop treatments, the highest cob yield was obtained from $T_{4}\left(14.25 \mathrm{t} \mathrm{ha}^{-1}\right)$. The lowest cob yield was recorded in $\mathrm{T}_{3}\left(12.64 \mathrm{t} \mathrm{ha}^{-1}\right)$ due to mainly for minimum number of cobs / plot. Similar to green cob yield, the highest green fodder yield was recorded in sole maize $(36.57 \mathrm{t}$ $\left.\mathrm{ha}^{-1}\right)$. In intercrop situation, higher green fodder yield was obtained from $\mathrm{T}_{4}\left(29.53 \mathrm{t} \mathrm{ha}^{-1}\right)$. Highest grain yield was found $9.63 \mathrm{t} \mathrm{ha}^{-1}$ in case of sole maize cultivation.

Effect on Chilli: Fruit yield and other yield attributes of chili were significantly affected by the maize + chili intercropping systems (Table 2). The highest number of fruits / plant was obtained from the treatment $\mathrm{T}_{4}$ (312). The lowest number of fruits / plant was obtained from $\mathrm{T}_{2}$ (283). The maximum fruit weight/plant was obtained from the treatment $\mathrm{T}_{4}(472.58 \mathrm{~g})$ and the lowest from $T_{2}(392.37 \mathrm{~g})$. Significantly the highest fruit yield $\left(9.52 \mathrm{t} \mathrm{ha}^{-1}\right)$ was observed in $T_{2}$ while the lowest from $T_{4}\left(5.43 \mathrm{t} \mathrm{ha}^{-1}\right)$. Variation in fruit yield ha ${ }^{-1}$ of chilli might be influenced by the plant population in the intercropping systems. Fruit yield increased with the increase of plant population.

Intercrop efficiency: Green Cob yield, fodder yield, green chilli yield and economic study of hybrid maize + Chilli intercropping system are presented in Table 1, 2 \& 3. Total yield in terms of cob yield (12.64 t ha $\left.{ }^{-1}\right)$, fodder yield $\left(26.64 \mathrm{t} \mathrm{ha}^{-1}\right)$, and green chilli yield $\left(7.96 \mathrm{t} \mathrm{ha}^{-1}\right)$ were lower than sole maize or sole Chilli. Among intercropping systems, higher cob yield, fodder yield was obtained from $\mathrm{T}_{4}$ due to higher cob yield $\left(14.25 \mathrm{t} \mathrm{ha}^{-1}\right)$ but in case of green chilli yield $5.43 \mathrm{t} \mathrm{ha}^{-1}$ which is lower than other intercrops. So, among intercropping systems $\mathrm{T}_{3}$ combination is more suitable than others due to higher gross return (Tk. $435040 \mathrm{ha}^{-1}$ ), net return (Tk. $366290 \mathrm{ha}^{-1}$ ) and benefit cost ratio (6.33) as compared to other combination.

Table 1. Yield and yield components of hybrid maize in maize +chilli intercropping under different planting systems

\begin{tabular}{l|c|c|c|c|c}
\hline Treatment & $\begin{array}{c}\text { Plants } \mathrm{m}^{-2} \\
\text { (no.) }\end{array}$ & $\begin{array}{c}\text { Cob weight } \\
\text { with husk } \\
(\mathrm{g})\end{array}$ & $\begin{array}{c}\text { Yield of green cob } \\
\text { with husk } \\
\left(\mathrm{t} \mathrm{ha}^{-1}\right)\end{array}$ & $\begin{array}{c}\text { Green } \\
\text { fodder yield } \\
\left(\mathrm{t} \mathrm{ha}^{-1}\right)\end{array}$ & $\begin{array}{c}\text { Grain yield } \\
\left(\mathrm{t} \mathrm{ha}^{-1}\right)\end{array}$ \\
\hline $\mathrm{T}_{1}$ & 6.67 & 387 & 17.58 & 36.57 & 9.63 \\
$\mathrm{~T}_{3}$ & 2.67 & 285 & 12.64 & 26.64 & 6.48 \\
$\mathrm{~T}_{4}$ & 4.00 & 312 & 14.25 & 29.53 & 7.56 \\
\hline $\mathrm{LSD}(0.05)$ & 2.48 & 2.89 & 0.97 & 0.94 & 2.02 \\
$\mathrm{CV}(\%)$ & 5.76 & 8.53 & 4.57 & 5.78 & 7.94 \\
\hline
\end{tabular}

Table 2. Yield and yield components of chilli in maize + chilli intercropping system

\begin{tabular}{l|c|c|c|c}
\hline Treatment & $\begin{array}{c}\text { Plants } \mathrm{m}^{-2} \\
\text { (no.) }\end{array}$ & $\begin{array}{c}\text { Fruit plant }^{-1} \\
\text { (no.) }\end{array}$ & $\begin{array}{c}\text { Fruit weight plant }^{-1} \\
(\mathrm{~g})\end{array}$ & $\begin{array}{c}\text { Fruit yield } \\
\text { (t ha }^{-1} \text { ) }\end{array}$ \\
\hline $\mathrm{T}_{2}$ & 4.38 & 283 & 392.37 & 9.52 \\
$\mathrm{~T}_{3}$ & 3.27 & 296 & 425.14 & 7.96 \\
$\mathrm{~T}_{4}$ & 2.68 & 312 & 472.58 & 5.43 \\
\hline LSD (0.05) & 3.48 & 12.57 & 14.67 & 2.44 \\
$\mathrm{CV}(\%)$ & 6.81 & 5.64 & 7.61 & 5.14 \\
\hline
\end{tabular}

Table 3. Benefit cost ratio analysis of maize-chilli intercropping under different planting systems 
Ahmed et al.

\begin{tabular}{l|c|c|c|c|c|c|c|c}
\hline Treatment & MEY & $\begin{array}{c}\% \\
\text { Increased } \\
\text { MEY over } \\
\text { sole maize }\end{array}$ & $\begin{array}{c}\text { Maize } \\
\text { grain } \\
\text { yield } \\
\left(\mathrm{t} \mathrm{ha}^{-1}\right)\end{array}$ & $\begin{array}{c}\text { Chilli } \\
\text { fruit } \\
\text { yield } \\
\left(\mathrm{t} \mathrm{ha}^{-1}\right)\end{array}$ & $\begin{array}{c}\text { Gross } \\
\text { return } \\
\left(\text { Tk. ha }^{-1}\right)\end{array}$ & $\begin{array}{c}\text { Total cost } \\
\text { of } \\
\text { production } \\
\left(\text { Tk. ha }^{-1}\right)\end{array}$ & $\begin{array}{c}\text { Gross } \\
\text { margin } \\
\left(\text { Tk. ha }^{-1}\right)\end{array}$ & BCR \\
\hline $\mathrm{T}_{1}$ & 9.63 & - & 9.63 & - & 173340 & 66750 & 106590 & 2.60 \\
$\mathrm{~T}_{2}$ & 21.16 & $(+) 120$ & - & 9.52 & 380800 & 63750 & 317050 & 5.97 \\
$\mathrm{~T}_{3}$ & 24.17 & $(+) 151$ & 6.48 & 7.96 & 435040 & 68750 & 366290 & 6.33 \\
$\mathrm{~T}_{4}$ & 19.63 & $(+) 104$ & 7.56 & 5.43 & 353280 & 68750 & 284530 & 5.14 \\
\hline
\end{tabular}

MEG : Maize equivalant yield

$\mathrm{T}_{1}$ : Sole maize $(60 \mathrm{~cm} \times 20 \mathrm{~cm}), \mathrm{T}_{2}$ : Sole chilli $(50 \mathrm{~cm} \times 40 \mathrm{~cm}), \mathrm{T}_{3}$ : Single row maize $(150 \mathrm{~cm} \times 25 \mathrm{~cm})$ +3 rows chilli $(50 \mathrm{~cm} \times 40 \mathrm{~cm}), T_{4}$ : Single row maize $(100 \mathrm{~cm} \times 25 \mathrm{~cm})+2$ rows chilli $(50 \mathrm{~cm} \times 40 \mathrm{~cm})$

Local market price $\left(T k . \mathrm{kg}^{-1}\right)$ : Maize grain $=18 /-$, Chilli $=40 /-$

\section{Conclusion}

The result revealed that single row maize $(150 \mathrm{~cm} \times 25 \mathrm{~cm})+3$ rows chilli $(50 \mathrm{~cm} \times 40 \mathrm{~cm})$ combination had higher equivalent yield and economic return than sole crop of maize and chilli. So, this combination might be suitable for improving crop productivity and economic return in the hilly areas.

\section{References}

Ahlawat, I. P. S. and R. P. Sharma. 2002. Agronomic Terminology. Indian Society of Agronomy, Division of Agronomy, Indian Agricultural Research Institute, New Delhi, India.

Aravazhi E., S. Natarajan and S. Thambaraj. 1997. Economics of intercropping in chilli. South Indian Hort. 45: 139-194.

BBS (Bangladesh Bureau of Statistics). 2012. Agricultural Statistical Yearbook of Bangladesh, 2014.

Francis, C. A., C. A. Flor and S. R. Temple. 1976. Adapting varieties for intercropping systems in the tropics. In: Papendick R. I., P. A. Sanches and G. B. Triplett. (eds.). Multiple cropping. Special publication number 27. Pp. 235-253. Madison. American Society of Agronomy.

Natarajan, S. 1992. Effect of intercrops on chilli (Capsicum annum L.) under semi dry conditions. South Indian Hort. 40: 273-276.

Ofori, F. and W. R. Stern. 1987. Cereal-legume intercropping systems. Adv. Agron. 41: 41-90.

Sadashiv, B. 2004. Production potential of hybrid cotton (Gossypium hirsutum) based vegetable intercropping systems under irrigation. M.S thesis, University of Agricultural Sciences, Dharwad, India.

Santalla, M., A. P. Rodino, P. A. Casquero and A. M. De Ron (2001). Interactions of bush bean intercropping with field and sweet maize. European J. Agron.15: 185-196. 